\title{
Student-Athlete Compensation: An Alternative Compensation Model for All Athletes Competing in NCAA Athletics
}

\author{
Mike Stocz, Ph.D. \\ University of North Alabama \\ Nicholas Schlereth, Ph.D. \\ Coastal Carolina University \\ Dax Crum \\ University of New Mexico \\ Alonzo Maestas \\ University of New Mexico \\ John Barnes \\ University of New Mexico
}

\begin{abstract}
Abstract: The Ed O'Bannon case (O'Bannon v. National Collegiate Athletic Association, 2015) has brought student-athlete compensation to the national spotlight. While the NCAA continues to defend its policy of amateurism, the time for college athlete compensation may soon become a reality (NCAA Division I Manual, 2019). Recent college athlete compensation models have explored revenue sharing models similar to that of professional sports leagues, although previous research failed to develop a compensation model for athletes in sports beyond basketball and football (Huma \& Staurowsky, 2013). The current research argues for a more applied, marketeconomy compensation model to offer fair compensation to collegiate athletes. This model takes into account the revenues generated by each university team, while also accounting for both the student-athlete and team's performances on and off the field. Justifications for this model are explored, as this model will allow for a new way to compensate athletes via on and off-field metrics. This paper concludes with an example of the model's utility through using publically accessible data for a major Division I college program.
\end{abstract}

Keywords: NCAA, student-athlete compensation, market economy, athletics, studentathlete

At the National Collegiate Athletics Association's (NCAA) annual convention in January, 2012, Association President Mark Emmert addressed what he called the "collegiate model" (NCAA Division I Manual, 2019, p. 6; Southall \& Staurowsky, 2013, p. 403) of college athletics and called for its reform so as to preclude the adoption of a "professional model" (Southall \& 
Staurowsky, 2013, p. 403). In his address, Emmert noted that while the collegiate model was in some respects outdated, he went on to say that this model was a better alternative than using a professional model in American college sport. Emmert's address in 2012 included a statement that noted the NCAA was at a fork in the road regarding the vast revenues involved in college sport (Southall \& Staurowsky, 2013).

The NCAA's concerns over the preservation of a model akin to amateurism in commercial college athletics, while hosting sports that generate revenue, are well founded. Despite being labeled as an amateur enterprise by the NCAA, certain college sports appear very similar in their operations to their professional counterparts. For example, much like professional football players, college football players compete at a high level and generate billions of dollars in revenue, as seen through the $\$ 2.25$ billion deal between ESPN and the Southeastern Conference (SEC) over a 15 year period (Smith \& Ourand, 2008). One of the main differences between college and professional sports is that those at the professional level are allowed to negotiate their pay through individual contracts and collective bargaining. College football players work under an artificial salary cap that limits compensation to what is allowed within a college scholarship (Moyer, 2015).

Since its inception, the popularity of college athletics has grown both steadily and exponentially (Santesteban \& Leffler, 2017). This growth has led to the continued evolution of athletics programs, in terms of departmental size, complexity, and ambition. The NCAA was forced to regulate and accommodate such differences in its defense of amateurism. This stance on amateurism has allowed for various lawsuits to threaten the current state of the NCAA, including the Ed O'Bannon case.

Previous research has questioned the NCAA's model for student-athlete compensation in terms of the quality of education athletes receive (Berry III, 2013), adequate compensation for athletes (Huma \& Staurowsky, 2013; Schott, 1996), and the removal of power from the studentathlete (Nestle, 1992). The current research aims to add to the various options that college athletics can utilize in compensating student-athletes. Rather than focus this paper's efforts on a discussion of anti-trust legislation and its relationship to the NCAA, the proposed model serves as an applied option for college athletics moving forward. In short, the proposed model will take two major factors into account: (a) a number of metrics to determine an individual student-athlete's payout total, and (b) a 14\% loading factor applied to that payout total. It should be noted that this model could be negotiated through a collective bargaining agreement and implemented on the university level through these negotiations. Furthermore, the crux of this model's development was inspired by the O'Bannon case. The O'Bannon case brought student-athlete compensation to the forefront of educational news, while its effects drew concern at the highest levels of the NCAA. Aspects from various legal cases will be observed, although these cases' purpose for this research was in furtherance of the proposed model as opposed to the generation of a legal argument.

\section{Literature Review}

In the paradigm of American college sport, it is taken for granted that collegiate sports be considered amateur in nature, as some sports have generated revenues for the NCAA totaling billions of dollars (Santesteban \& Leffler, 2017; Steele, 2015). As such, this literature review 
begins with an overview of amateurism and the NCAA, followed by relevant legal literature pertaining to the proposed formula.

Amateurism in college sports was derived from $19^{\text {th }}$ century England, where it was used as a common mechanism to create economic and social stratification in sport. Wealthy elites were able to use strict amateur standards to exclude working people from the competitions, as the wealthy would compete, in their view, for love of the game rather than for monetary compensation (Dennie, 2012). These standards would eventually be the basis for intercollegiate athletics in the United States, which included a strict code of amateurism. This level of strictness was shown through Harvard's ban on gate receipts at athletic contests during the late 1800's. Eventually, the Intercollegiate Athletic Association of the United States (IAAUS), the former name of the NCAA, was organized in 1906 to adopt and enforce strict amateurism standards (Dennie, 2012).

According to NCAA Division I Manual (2019) Bylaw 2.9, "student-athletes shall be amateurs in an intercollegiate sport, and their participation should be motivated primarily by education and by the physical, mental and social benefits to be derived" (p. 10). Amateurism is further defined in Bylaw 2.13 as prohibiting "financial assistance" to student-athletes from all parties other than legal guardians or the institution for which the student-athlete participates in athletics. The institution is then further limited to providing financial assistance not to exceed the "cost of education authorized by the association also known as the "cost of attendance"" (NCAA Division I Manual, 2019, p. 11). The NCAA goes on to describe amateurism as an "avocation," or hobby, where "student-athletes should be protected from exploitation by professional and commercial enterprises" (NCAA Division I Manual, 2019, p. 10).

In clarifying what the word amateurism means as applied to college athletics, the late NCAA President Myles Brand stated that while amateurism describes how one would participate, it does not describe the enterprise. He followed that statement with a call to "not be ambivalent about doing the business of college sports" (Otto \& Otto, 2013, p. 260). Brand was attempting to uncouple the athlete from the sport so that defining one would not mean defining the other. This would allow the NCAA to reap the benefits of being a commercial enterprise without having to pay the costs of the labor (Otto \& Otto, 2013).

Brand's definition of amateurism may be perceived as faulty and out-of-date given the current state of sports revenues generated by the NCAA and its member institutions. The NCAA recently surpassed revenues of $\$ 1$ billion annually (Kirshner, 2018). In 2013, immense popularity of Division I college football generated a total of $\$ 3.4$ billion in total revenue by member institutions, and in 2014, the Top-50 NCAA football programs alone generated $\$ 5.2$ billion in total revenue (Santesteban \& Leffler, 2017; Steele, 2015). Over the past ten years, NCAA football revenue has risen more than 200 percent; by comparison, the National Hockey League (NHL), as one of the big-four professional sport leagues, reported a total of $\$ 3.7$ billion in revenues in 2013 (Steele, 2015). The economic realities of $21^{\text {st }}$ century commercial college athletics, particularly football and men's basketball, no longer justify strict restriction of student-athlete compensation. In fact, some have suggested that the NCAA failing to compensate student-athletes stems from neoliberal and racist ideologies deeply rooted in NCAA host institutions (Gales, Comeaux, Ofoegbu, \& Grummert, 2018). These researchers suggested that the NCAA is the commercial 
enterprise solely reaping the benefits of student-athlete exploitation. These realities were put on public display through the Ed O'Bannon case.

O'Bannon vs. NCAA (2014) has changed the landscape of college athletics. Ed O'Bannon starred on the UCLA team that won the NCAA National Basketball Championship in 1995. Following his immense college success, O'Bannon continued his career in the National Basketball Association (NBA). In 2009, he filed suit against the NCAA and Electronic Arts (EA) Sports for the continued use of his name and likeness without providing him any compensation for that use, even more than a decade after he was no longer a collegiate athlete. Two years later, O'Bannon was joined in the lawsuit by former college and professional basketball player Oscar Robertson. The plaintiffs argued that in order for them to be eligible for participation in college sports, they were forced to sign a Student-Athlete Statement. By signing this statement, they authorized the NCAA and its licensees the use of their names and likenesses in perpetuity without having to share one penny of the profit with those athletes (O'Bannon v. National Collegiate Athletic Association, 2014). O'Bannon argued that forcing athletes to sign away their rights to any income from the use of their image, especially without the help of legal counsel, was exploitation and that the policy created an undue restraint of trade. In addition, O'Bannon contended that not allowing former student-athletes to share in the profits generated by the use of their names and likenesses long after their college careers end served no legitimate purpose, which violated antitrust legislation (O'Bannon v. National Collegiate Athletic Association, 2014).

Despite the NCAA's success in eliminating a least restrictive compensation model for athletes derived from the O'Bannon case at the district level (O'Bannon v. National Collegiate Athletic Association, 2014), the concept was introduced to commercial collegiate athletics. The NCAA argued against O'Bannon by suggesting their amateur system was the only way to effectively continue to integrate academics and athletics while maintaining the competitive balance of its athletic contests (O'Bannon v. National Collegiate Athletic Association, 2014). Judge Wilken rejected the argument that totally restricting athlete compensation was necessary to maintain a competitive balance. In fact, allowing a more reasonable system of compensation may balance, and possibly increase, the level of competition and demand (Arash, 2014; Greene, 2012). Judge Wilken did, however, agree with the NCAA that large lump-sum payments to athletes during participation may have a negative impact on the competitive balance and lead to more athlete exploitation, especially if third parties were freely capitalizing on athlete talents, likenesses, and celebrity. If compensation beyond athletic expenses could be held in a trust by member schools until participation was completed, both the needs of the NCAA and athletes would be more justly fulfilled (Moyer, 2015). Additionally, other researchers suggested that athletic competitive balance would not be affected by the introduction of player compensation; rather it may more effectively counteract existing competitive advantages in recruiting held by major universities (Mills \& Winfree, 2018).

It should be noted that the NCAA appealed the district court's decision in $O^{\prime}$ Bannon $v$. National Collegiate Athletic Association, 2015. The NCAA argued that O'Bannon did not successfully meet the standard for a Sherman Act claim, and that the plaintiffs failed to reach the merits of the case itself. On appeal, the courts found that given the current and proposed funding systems, to allow NCAA members to pay cash outright to student-athletes instead of granting scholarships would be a quantum leap. The appellate court then vacated the district court's 
decision, thus allowing the NCAA to retain its standard of amateurism. O'Bannon filed a Writ of Certiorari that the Supreme Court would deny. However, two other cases have challenged the NCAA's existing compensation model.

In Alston v. NCAA, the plaintiffs argued that allowing the NCAA to cap the value of athletic scholarships runs afoul of the law, as it does not allow conferences and universities to compete with each other (McCann, 2018b). The NCAA relied, in part, on the appellate court's O'Bannon decision, stating that allowing Alston to succeed would make the NCAA a minor league for professional sports. In Jenkins $v$. NCAA, the plaintiffs argued that the NCAA's practice of capping the value of athletic scholarships is anti-competitive, and asked Judge Wilken, who also presided over O'Bannon and Alston, to issue an injunction changing the way the NCAA operates moving forward (McCann, 2018a). Both of these cases may end up doing what O'Bannon did not: change the NCAA's compensation model for student athletes. No matter the case outcome, appeals are likely, as this process may go on for some time.

The compensation of college athletes seems to be an ongoing issue, although compensation of college athletes and providing fair compensation are two distinct issues. If colleges and universities existed in a free market for obtaining their player labor, each would compete for those athletes, but the competition would be based on the pay and benefits being offered. But, because the compensation for player labor is restricted to the cost of attendance, such competition is not necessary. In essence, the NCAA and its member institutions collude to fix wages (Sanderson \& Siegfried, 2015). Were this not the case, finding an equitable and legal system of compensation would be difficult, further escalating the college sport "arms race for talent" (Santesteban \& Leffler, 2017, p. 109).

For example, based upon conventional methodology, in NCAA Division I (D-I) men's basketball, about $60 \%$ of the players on a team generate revenue above and beyond the value of their athletic scholarship. Using that figure, approximately 40 to 50 of the 85 scholarship athletes on a D-I football team would generate revenue beyond the value of their scholarship (Sanderson $\&$ Siegfried, 2015). The relatively large discrepancies in wage potential between those players who derive revenue for their school, and those who do not, provide reason for pause; however, competitive markets are based upon compensation that provides more for those who create larger marginal products (Sanderson \& Siegfried, 2015).

Huma and Staurowsky (2013) examined student-athlete compensation via a report from the National College Players Association. They utilized a model of compensation based on the common revenue sharing system experienced in professional sports. In their model, football and men's basketball players were the only athletes to receive compensation, with football players receiving about $\$ 150,000$ and men's basketball players receiving close to $\$ 230,000$ annually. Their claim and rationale was based on a free market system. Zimbalist (2010) proposed that player revenue shares across the big four professional sport leagues (NFL, MLB [Major League Baseball], NBA, and NHL) vary from year to year, based more on what each team actually spends as opposed to deals reached through collective bargaining. The NFL's range of player compensation as a percentage of total revenue ranged from 54.3\% in 2005 to $62.1 \%$ in 1994, while the salary share of basketball related income in the NBA ranged from 53\% in 1995-1996 to 65\% in 2000-2001. Moreno and Lozano (2015) found that team efficiency has started to become the 
new norm for athlete compensation in the NBA as the more successful teams use their funds efficiently to get the most production for their investments. These findings suggest that NBA franchises are going more towards a sabermetrics approach for developing their team rosters. Sabermetrics have evolved from a simple statistical analysis for top-tier player talent (Costa, 1991) to a tool used to predict baseball success based on in-game productivity (Anthony, 2009). This tool can be used as a means of individual performance, which has been used widely in the MLB with application attempts on the rise in the NFL.

One approach to providing compensation to college athletes, while preserving some semblance of amateurism, is to adopt a mechanism utilizing trust funds, similar to the Olympic Model. The NCAA has staunchly defended the position that college athletes are students first, and success of the entire enterprise hinges upon athletes remaining unpaid "amateurs." Even the term "student-athlete" was devised to subjugate athletes into a state of permanent amateurism (NCAA Division I Manual, 2019; Staurowsky \& Sack, 2005). The only organization to rival the NCAA's defense of amateurism on such a large scale was the International Olympic Committee (IOC). The IOC, like the NCAA, had one hard and fast rule: the Olympic Games were for amateurs only, and athletes who received compensation were exploiting the very essence of games for personal benefit. The IOC held that commercialization of the Olympics would only further destroy this essence (Greene, 2012). In 1972, the new leadership of the IOC explored both the commercial interests of the games and athlete compensation. When the greatest and most famous athletes competed, it attracted viewers. The increased viewership of the games enticed advertisers, which led to more lucrative television contracts. In the 1980's, athletes commonly received subsidies or compensation for athletic expenses incurred in the pursuit of Olympic participation (Arash, 2014). Athletes were soon compensated for more than expenses and could use their prestige and visibility to maximize their utility in the free market.

Unlike the IOC, the NCAA has yet to allow athletes the right to benefit from a market economy (NCAA Division I Manual, 2019). In O'Bannon v. NCAA, Judge Wilken offered a substantial remedy that successfully satisfied, for a short time, the interests of both the NCAA and the athletes $\left(O^{\prime}\right.$ Bannon $v$. NCAA, 2014). Wilken's remedy involved allowing the:

NCAA's no-pay rules [to] remain in force but the organization may also adopt a definition of compensation and benefits that is "related to education" for the purposes of complying with the judge's order...allowing each conference and its member schools to provide additional education-related benefits without NCAA caps and prohibitions, as well as academic awards... (O'Bannon v. NCAA, 2014)

The success of the Olympic Model and this judicial remedy served as inspiration for the proposed model of student-athlete compensation.

The purpose of this research was to provide the first competitive model of athlete compensation, which provides consideration to student-athletes based on a market economy. This model has the potential to adequately and practically provide student-athletes with an equitable share of the revenue they help produce for their athletic departments. In this manner, studentathletes in sports such as track and field, golf, soccer, etc., will have the opportunity to make financial gains. This model takes into account a multitude of factors, including team performance, 
the percentage of revenue produced by each individual athletic team, and individual performance. Before its introduction, some of the direct and closely-related literature will be examined to inform the model. The model specifics will then be presented along its direct application via a case study methodology. Finally, a brief discussion of the implications and future directions for this model, and the limitations, will follow.

\section{Conceptual Framework}

\section{New Revenue Distribution Model}

Institutes of higher learning have a choice - they may choose to allow a purely free market economy approach that dictates the student-athlete market, or they may choose to use some of the models previously overviewed. A pure free market approach, however, may require a collective bargaining agreement between the NCAA and its institutions, as well as the student-athletes. The turnover for student-athletes is apparent and could lead to a new collective bargaining agreement to be negotiated every four years to allow for the current student-athletes to contribute to the negotiations. Continually adopting a new collective bargaining agreement may not be in the best interest of the NCAA or the student-athletes, as professional leagues have seen a loss of revenues from negotiating new agreements.

The revenue sharing model presented in this paper mandates that individual teams within a university's athletic department that generate over $33 \%$ of the revenue will redistribute this revenue to other teams within the same athletic department. This model will apply at the university level as opposed to the NCAA level. The proposed model introduces a formula to derive the value that the student-athlete provides to a team. The student-athlete portion of this formula essentially suggests what percentage of revenue each athlete contributes to their team on and off the field. This model is an attempt to derive the value created by the athlete to the athletic department to ensure a fairer compensation model. This model was not based solely on a pure market economy type model, as this model sought to compensate all college athletes, not just those in the most prominent college sports.

Huma and Staurowsky (2013) also provided a model for compensating basketball and football players with the notion that they are the significant revenue producers for their athletic department. After reviewing individual team revenues, each team did produce some revenue for their athletic department. While each team was not able to fully support itself, the student-athletes were still representing their athletic department in an activity that produces revenue for the entirety of the department, which included their team.

Under the proposed model, the cost of attendance factor implemented by the NCAA would be revoked and replaced with a comparable allowance from the individual student-athlete's claim on overall revenues of the athletic department (NCAA Division I Manual, 2019). The cost of attendance figure can be viewed as a prohibitory force to athletes, recognizing their full earning potential from the athletic department. The proposed model introduces a means for the athlete to receive a fair share of the athletic departments' revenues while also ensuring the student-athlete could achieve academic success and graduate. An athlete will have an immediate payout based on 
a percentage total, derived from on and off field metrics, with the rest of their earned funds being held in a trust fund that will be released after the student graduates.

Graduation from school is a foundational element of this model and is a dominant reason for excess earnings that are not received during the fiscal year to be kept in a trust fund, contingent upon graduation. A student-athlete should have to uphold their end of the agreement with the athletic department and university to strive for academic success. "Financial assistance," otherwise known as and used interchangeably as "financial aid," "grant-in-aid," and "a scholarship," are referred to as an amount of money that is given by an institution to pay for the student's education (NCAA Division I Manual, 2019). Financial assistance is intended to be utilized for a student's education and the student-athlete should uphold their end of the relationship in graduating from school.

The percentage claim on revenues for a student-athlete will be comparable to the percentage that cost of attendance figures into the overall grant-in-aid for the student-athlete (NCAA Division I Manual, 2019). The formula for deriving the claim a student-athlete has on the generated revenues for the year equates to the average cost of attendance (e.g., tuition and fees, room and board) compiled by the U.S. Department of Education, and the average cost of attendance expense for schools in the Division I Football Bowl Subdivision (FBS) category. According to the U.S. Department of Education, the average cost of attendance per year for a four year institution (private and public) was $\$ 23,872$ (U.S. Department of Education, 2015). Solomon (2015) produced a database with the expense for schools in FBS schools, revealing that the average cost of attendance stipend came out to $\$ 3,814$.

Previous literature does not provide clear guidance on a specific metric to utilize in determining the proper methodology for deriving the equitable share of revenue for studentathletes. This metric was surmised using the amount of the overall expense for grant-in-aid provided to the student-athlete. Since this model will take away cost-of-attendance for the studentathlete, this void will be filled by providing the same percentage of overall revenue for studentathletes. The breakdown for the proposed model is $14 \%(\$ 23,872+\$ 3,814=\$ 27,686$, then $\$ 3,814 / \$ 27,686=0.14)$. A further breakdown of the formula that will be utilized in determining athlete value to the team will be explained in the next section.

\section{Methodology}

\section{Formula Development and Justification}

A pragmatic and inductive approach was used to compose the proposed model for athlete compensation. The model has been broken down piece by piece as a guide for usage by athletic personnel. This model assumes that athletes will start with zero compensation with the opportunity for gaining funds based off of on-field contributions, winning percentages, and other benchmarks described within. Again, this model should be seen as a potential tool for the NCAA and its member institutions as a fair way to compensate athletes. The model itself takes into consideration both the university and athlete's needs by allowing a player's talent to determine compensation while allowing the university to clearly delineate which players will receive compensation. While this model eliminates some bias, it does not eradicate it completely; other arguments for collective 
bargaining and anti-trust laws can be seen through court cases or other academic works (Berri, 2012; Hilly \& Jolly, 2015; Moyer, 2015).

As previously stated, $14 \%$ of the revenue generated by NCAA member institutions goes toward covering cost of attendance on average, or college expense $(C E)$ per athlete. Simply put, $14 \%$ of the revenue generated by the university on average would go towards funding a studentathlete's $C E$, including tuition, books, room and board, and miscellaneous costs. In recent history, prominent sports leagues such as the NFL have used up to $68.5 \%$ of their total revenue towards player compensation while the NBA players accounted for $57 \%$ of the income generated through the league and league activities (Berri, 2012; Vrooman, 2012). This model proposed an elimination of the cost of attendance stipend, instead paying athletes this $14 \%$ (roughly) outright.

The variables introduced here were reverse engineered from two overarching factors: the player cap and the player compensation coefficient. These variables were chosen because the equation is based on the most money a player can receive as opposed to starting with a zero total for athlete compensation. From there, multiplying the highest total by the player compensation coefficient would lead to the final pay out to the student-athlete. Variables within the player cap total are discussed below, as the player compensation coefficient is discussed from a broader perspective. The equations are presented in a logical flow, from the beginning of the process to the end.

First, $14 \%$ of the total revenue generated by each individual sport within a school will be allocated not toward scholarships and other $C E$ expenses, but rather toward a separate account, or Student-Athlete Fund $(S A F)$. Team revenue $(T R)$ could be generated via ticket sales, sponsors, and television revenue. The following equation represents this fund generation, with different sports represented by $S$ :

$$
S A F=\Sigma\left(\left(0.14\left(T R S_{1}\right)\right)+\left(0.14\left(T R S_{2}\right)\right)+\left(0.14\left(T R S_{3}\right)\right) \ldots\right)
$$

The $S A F$ will then be dispersed to each team within a school in a manner similar to revenue sharing practices in MLB. The MLB commissioned the Blue Ribbon Panel to find a solution toward their top-heavy success (Hill \& Jolly, 2015). Clubs were taxed into the revenue sharing model of the MLB, which taxed every team but favored taxing teams with higher overall team salaries. A cap limit was set on taxing high spenders to keep the league competitive for free agency issues.

This model proposes that teams would receive a percentage (Percentage of Total Revenue $[P T R]$ ) of the $S A F$ based on the total revenue they acquire. This number was extrapolated from the revenue $(T R)$ brought in by a sport (plus an equal percentage of revenue not related to specific teams [RNRST], symbolized by $S R V$ ) divided by grand total revenue $(G T R)$. This percentage of a team's claim on the $S A F$ will be capped at $33 \%$.

$$
\begin{gathered}
P T R_{1}=S R V_{1} / G T R ; P T R_{2}=S R V_{2} / G T R \ldots \\
S R V_{1}=T R_{1}+R N R S T
\end{gathered}
$$


Non-adjusted totals (NAT) would then be generated by multiplying a team's $P T R$ by the overall $S A F$. The NAT score represents a baseline for each team's eventual student-athlete fund for that particular team.

$$
N A T_{1}=P T R_{1} * S A F ; N A T_{2}=P T R_{2} * S A F
$$

For teams over the 33\% athletes mark, the difference between the NAT and the adjusted total $(A T)$ would then be distributed between the number of teams below the $33 \%$ threshold $(L T)$. $A T$ will recalculate the team's total at the $33 \%$ mark. For all other teams, the new additive is symbolized by $G A$.

$$
\begin{gathered}
G A=N A T_{1}-A T_{1} \\
A T_{1}=\left(P T R_{33}\right) *(S A F)
\end{gathered}
$$

The $G A$ total would be added to all teams below the $33 \%$ threshold for the new added totals $(A D T)$. The total amount of funds redistributed to teams will be based on the number of athletes (TA) per team. First, find the total number of athletes on teams with a PTR below 33\% (BTA). Divide the $G A$ by the $B T A$ total, and multiply the result $(M P A)$ by the number of athletes on a team. Add this total $(A D M)$ to each team.

$$
\begin{aligned}
& B T A=\Sigma\left(T A_{33 \%}>\mathrm{PTR}\right)+\left(T A_{33} \%>\mathrm{PTR}\right) \ldots \\
& M P A=G A / B T A \\
& A D M_{1}=\left(T A_{33} \%>\mathrm{PTR} 1\right) *(M P A) \\
& A D T_{1}=A D M 1+N A T_{1} ; A D T_{2}=A D M_{2}+N A T_{2} \ldots
\end{aligned}
$$

It should be noted that the teams above $33 \%$ will not receive this adjustment, and administrators should use the formula $P T R_{\text {Above } 33 \% \text { Teams }}=A D T_{\text {setat }} 33 \%$. After determining the $A D T$ figures, individual player compensation must then be addressed. Camara (2009) proposed that a company must exceed a certain threshold of earnings before they pay a bonus to their managers/employees. In other words, managers and employees must meet a certain threshold performance. This model acknowledges that not all student-athletes will meet these thresholds. Thus, this model will be based off of the maximum amount a person can obtain from the ADT and number of participants per team. This player cap $(P C A)$ is the maximum amount an athlete can receive. The sum of a team's athletes is shown by the symbol TA. PCA totals apply to a whole team (i.e., football, women's basketball, etc.).

$$
P C A_{1}=A D T_{1} /\left(T A_{1}\right) ; P C A_{2}=A D T_{2} /\left(T A_{2}\right) \ldots
$$

These funds are only for those who participated in the current season of their respective NCAA sport, with compensation being applied at the end of the season in two ways: $14 \%$ will go to the athletes as compensation, while $86 \%$ will remain in a trust fund that will be rewarded after successful completion of a bachelor's (or graduate) degree.

Three factors will determine an individual's payment from each sports team: Sport Visibility $(S V, 33 \%)$, Team Success (TM, 34\%), and Individual Statistics (IS, 33\%). Each factor would need to be defined per sport, but in general, each factor would have some commonalities (shown in Figure 1). $S V$ components would include ticket sales, number of sellouts, nationally televised games, social media presence, and a loading factor that compares the estimated reach of 
that particular team versus teams within a similar sport. For example, a smaller Division I school may not have the same visibility in volleyball as larger Division I schools in more established programs. Next, $T M$ would be determined by a number of factors, such as having a winning record, conference tournament appearances, conference championship appearances, NCAA Tournament Appearances, and NCAA Tournament Championships. Last, IS would account for various individual player statistics, which would amount to different measurements by sport, but would include a team leader in certain statistics depending on the sport (i.e., strikeouts per season, receiving touchdowns, etc.), individual starts for the team, appearances for team (in-game), conference leader in a certain statistic, and NCAA statistical leader for a game, a season, and/or a career in a certain statistic.

Adding these factors together will equate to the Player Compensation Coefficient. Camara (2009) posited that a non-sports entity would not pay a bonus to their managers/employees until a certain threshold of earnings was exceeded. Stated differently, a certain threshold performance must then be met by their managers/employees to receive a bonus. This model assumes that not all student-athletes will meet these thresholds. These funds are only for those who participate in the current season of their respective NCAA sport, with compensation applied at the end of the season in a trust fund at $86 \%$, while actually receiving $14 \%$. Immediately following this part of the equation, the final equation would be used to determine what a player will receive for a season. The following baseline should be utilized to determine each factor for the Player Compensation Coefficient:

$$
(P C E)=S V+T M+I S
$$

Figure 1. Player Compensation Coefficient (PCE)

\begin{tabular}{l|ll}
\hline Sport Visibility $(S V)$ & $\begin{array}{l}\text { Can add up to 33\% or } \\
0.33\end{array}$ & $\begin{array}{l}\text { Accounted for via ticket sellouts for } \\
\text { games }(T S) \text {, number of nationally } \\
\text { televised games }(T V) \text {, social media } \\
\text { presence }(S M S)\end{array}$ \\
Team Success $(T M)$ & $\begin{array}{l}\text { Can add up to 34\% or } \\
0.34\end{array}$ & $\begin{array}{l}\text { Accounted for via winning record } \\
\text { (WR), conference tournament } \\
\text { appearances }(C T), \text { conference } \\
\text { championship appearances }(C C), \\
\text { NCAA Tournament Appearances } \\
\text { (NCAAT), NCAA Tournament } \\
\text { Championships }(N C A A C)\end{array}$ \\
& \\
&
\end{tabular}




\begin{tabular}{|c|c|c|}
\hline $\begin{array}{l}\text { Individual Statistics } \\
(I S)\end{array}$ & $\begin{array}{l}\text { Can add up to } 33 \% \text { or } \\
0.33\end{array}$ & $\begin{array}{l}\text { Team Leader in a positive category } \\
(T L), \text { Individual starts for a team } \\
\text { over the course of a season versus } \\
\text { number of team games played }(S T) \text {, } \\
\text { Individual appearances for a team } \\
\text { over the course of a season versus } \\
\text { number of team games played }(A P) \text {, } \\
\text { Conference Leader in a positive } \\
\text { category }(C L) \text {, NCAA individual } \\
\text { stat leader for a game }(N C A A I S) \text {, } \\
\text { NCAA individual stat leader for a } \\
\text { season }(N C A A S S) \text {, NCAA } \\
\text { individual stat leader for a career } \\
(N C A A S L)\end{array}$ \\
\hline
\end{tabular}

Should this coefficient equal 1 , then that athlete would receive the maximum funds available at the player cap. The final result will be multiplied by each year's player cap $(P C A)$ to discover how much the NCAA will pay these athletes for their efforts. $P C E$ indicators will need to be determined by sport by either the individual institutions or the NCAA. Finally, the athlete compensation (total) is represented by $A C$.

$$
A C_{1}=\left(P C E_{1}\right) *\left(P C A_{1}\right) ; A C_{2}=\left(P C E_{2}\right) *\left(P C A_{1}\right) ; A C_{3}=\left(P C E_{3}\right)^{*}\left(P C A_{2}\right) \ldots
$$

To show what this equation would look like in practice, the authors obtained a revenue statement for the University of Colorado. The University of Colorado was chosen as it was found that, after a review of athletic department revenues as reported through the United States Department of Education Equity in Athletics database, the University of Colorado's departmental revenues were close to the mean of NCAA FBS athletic departments. Furthermore, the University of Colorado was a member of a Power Five conference in 2015. Thus, the University of Colorado was deemed an adequate site to test this model.

The University of Colorado posted their NCAA financial report in 2015, containing a breakdown of revenues and expenses for each of their sports. Furthermore, the revenues and team numbers reported there were used through each step of this model. There were some surprises, such as the potential financial gains for men's and women's golf, that are explained in the discussion section. 
Table 1

Application to the University of Colorado (2015)

\begin{tabular}{|c|c|c|c|c|c|c|c|c|}
\hline Sport & PTR & $N A T$ & $\begin{array}{c}\text { Adjust over } \\
\mathbf{3 3 \%} \\
\end{array}$ & Difference & Add & Adjustment & $T A$ & Player Cap \\
\hline M BBALL & $12.48 \%$ & $\$ 1,145,488.55$ & $\mathrm{NO}$ & & $103,125.72$ & $1,248,614.27$ & 17 & $\$ 73,447.90$ \\
\hline W BBALL & $3.96 \%$ & $\$ 363,225.53$ & $\mathrm{NO}$ & & $103,125.72$ & $466,351.25$ & 13 & $\$ 35,873.17$ \\
\hline $\begin{array}{l}\text { M X CNTRY, } \\
\text { T\&F }\end{array}$ & $3.50 \%$ & $\$ 321,169.53$ & $\mathrm{NO}$ & & $103,125.72$ & $424,295.25$ & 236 & $\$ 1,797.86$ \\
\hline $\begin{array}{l}\text { W X CNTRY, } \\
\text { T\&F }\end{array}$ & $3.58 \%$ & $\$ 328,534.79$ & $\mathrm{NO}$ & & $103,125.72$ & $431,660.51$ & 216 & $\$ 1,998.43$ \\
\hline FOOTBALL & $46.49 \%$ & $\$ 4,265,857.97$ & $\$ 3,028,349.39$ & $\$ 1,237,508.59$ & & $3,028,349.39$ & 112 & $\$ 27,038.83$ \\
\hline M GOLF & $3.52 \%$ & $\$ 323,388.11$ & $\mathrm{NO}$ & & $103,125.72$ & $426,513.83$ & 6 & $\$ 71,085.64$ \\
\hline W GOLF & $3.59 \%$ & $\$ 329,706.31$ & NO & & $103,125.72$ & $432,832.03$ & 8 & $\$ 54,104.00$ \\
\hline W LAX & $3.85 \%$ & $\$ 353,288.61$ & $\mathrm{NO}$ & & $103,125.72$ & $456,414.33$ & 31 & $\$ 14,723.04$ \\
\hline M SKI & $3.44 \%$ & $\$ 315,306.89$ & NO & & $103,125.72$ & $418,432.61$ & 11 & $\$ 38,039.33$ \\
\hline W SKI & $3.58 \%$ & $\$ 328,711.33$ & $\mathrm{NO}$ & & $103,125.72$ & $431,837.05$ & 13 & $\$ 33,218.23$ \\
\hline W SOCCER & $4.44 \%$ & $\$ 407,257.21$ & $\mathrm{NO}$ & & $103,125.72$ & $510,382.93$ & 30 & $\$ 17,012.76$ \\
\hline W TENNIS & $3.54 \%$ & $\$ 324,868.89$ & $\mathrm{NO}$ & & $103,125.72$ & $427,994.61$ & 8 & $\$ 53,499.33$ \\
\hline VOLLEYBALL & $4.03 \%$ & $\$ 370,012.59$ & $\mathrm{NO}$ & & $103,125.72$ & $473,138.31$ & 17 & $\$ 27,831.67$ \\
\hline
\end{tabular}

\section{Student-Athlete Consideration}

As discussed in the previous section, $14 \%$ of each student-athlete's revenue allotment will be immediately available filling the void left from the removal of the cost-of-attendance stipend. The remaining $86 \%$ will be placed in a trust fund that the Federal Court has already deemed as an acceptable method of compensation for the student-athlete to recover once they graduate from school (Moyer, 2015). If a student-athlete leaves early from school for professional sports, they have five years to complete their degree or the funds that they collected in the trust fund are given back to the athletic department's scholarship fund. 
Figure 2. The Student-Athlete Compensation Model

\begin{tabular}{|c|c|}
\hline Determine Overall Student-Athlete & $S A F=\Sigma\left(\left(0.14\left(T R S_{1}\right)\right)+\left(0.14\left(T R S_{2}\right)\right)+\left(0.14\left(T R S_{3}\right)\right) \ldots\right)$ \\
\hline Determine How Much Each Team Will & $P T R_{1}=S R V_{1} / G T R ; P T R_{2}=S R V_{2} / G T R \ldots ;$ \\
\hline & $S R V_{1}=T R_{1}+R N R S T$ \\
\hline $\begin{array}{l}\text { Determine Each Team's Baseline } \\
\text { Student Distribution Funds }\end{array}$ & $N A T_{1}=P T R_{1} * S A F ; N A T_{2}=P T R_{2} * S A F$ \\
\hline Determine Adjustment Totals Overall & $\begin{array}{l}G A=N A T_{1}-A T_{1} ; \\
A T_{1}=\left(P T R_{33} \%\right)^{*}(S A F)\end{array}$ \\
\hline $\begin{array}{l}\text { Determine Adjustment Totals Per Team } \\
\text { (Based On Number of Athletes) }\end{array}$ & $\begin{array}{l}B T A=\Sigma\left(T A_{33 \%>\mathrm{PTR}}\right)+\left(T A_{33 \%>\mathrm{PTR}}\right) \ldots ; \\
M P A=G A / B T A ; \\
A D M_{1}=\left(T A_{33} \%>\mathrm{PTR} 1\right)^{*}(M P A) ; \\
A D T_{1}=A D M 1+N A T_{1} ; A D T_{2}=A D M_{2}+N A T_{2} \ldots\end{array}$ \\
\hline $\begin{array}{l}\text { Determine Maximum Amount A Player } \\
\text { Can Receive (Maximum) }\end{array}$ & $P C A_{1}=A D T_{1} /\left(T A_{1}\right) ; P C A_{2}=A D T_{2} /\left(T A_{2}\right) \ldots$ \\
\hline $\begin{array}{l}\text { Standards For Athlete Payout (Player } \\
\text { Compensation Coefficient) }\end{array}$ & See Figure 1 \\
\hline Determine Athlete Payout & $\begin{array}{l}A C_{1}=\left(P C E_{1}\right) *\left(P C A_{1}\right) ; A C_{2}=\left(P C E_{2}\right)^{*}\left(P C A_{1}\right) \\
A C_{3}=\left(P C E_{3}\right) *\left(P C A_{2}\right) \ldots\end{array}$ \\
\hline $\begin{array}{l}\text { Determine Athlete Payout At Year's } \\
\text { End }\end{array}$ & $\left(A C_{1}\right)^{*} 0.14$ \\
\hline Determine Athlete Payout to Trust Fund & $\left(A C_{1}\right) * 0.86$ \\
\hline
\end{tabular}

\section{Discussion}

Although the Ed O'Bannon case was not heard by the Supreme Court, this case brought the idea of athlete compensation to the public arena. The proposed model aims to serve college athletics as a functional option, should the issue of student-athlete compensation need a realistic solution. This model takes absolutely nothing away from the NCAA, and in the spirit of sabermetrics (though not born from sabermetrics), this model demands efficiency for a player to receive maximum compensation. Sabermetrics may find a home in this model when determining what would constitute a full $P C E$ value for student-athletes, but this needs to be explored further per sport. This model was created for a broad application, and to get scholars and practitioners alike to begin a dialogue on how to fairly compensate student-athletes. There is no magic answer to this issue, but the authors assert that this set of formulas should serve as a ground-level base for further development. 
Many who are reading this article will take issue with some of the results from the case study presented. For example, a men's golfer in this formula application has the opportunity to make over $\$ 71,000$ based on the University of Colorado's financial records. This can be explained by the ways in which administrators reported revenues. In a sport such as golf, donations such as golf clubs, rounds at a golf course, and sales through the golf course of university approved merchandise may be reported as part of the sport's overall revenue. For this equation to work, the NCAA and individual institutions need to truthfully report their revenue based solely on monetary transactions and donations, not gifts in kind (i.e., rounds of golf at a golf course, donated equipment, etc.). Furthermore, these results are unique to the University of Colorado and not to every school in Division I.

Sports such as track and field had results that may look subpar in terms of athlete compensation. Athletes in this group, however, are often represented through indoor and outdoor track and field, alongside cross country. In other words, these athletes have the potential to make up to three times the amount listed if they participate in all other sports. Other examples of this would include volleyball and beach volleyball, or multiple-sport athletes. Football, and potentially basketball, can act as a moderator to allow athletes to be compensated, a practice already in place across universities and colleges.

This Student-Athlete Compensation Model answered the call of Schott (1996) when he asserted that "other alternatives to the free market system must be explored in an effort to provide compensation to student-athletes" (p. 43). There is a presence of a free-market economy in the Student-Athlete Compensation Model, as an athlete's potential salary is determined in part by purchasing of tickets to athletic events. The Student-Athlete Compensation Model does not nestle within solely one economic background, but several, as the issue of compensating student-athletes is complex. The factors introduced within the Student-Athlete Compensation Model do need to be explored further as each specific sports metrics for athlete performance need to be addressed. The Student-Athlete Compensation Model presented here should act as the starting point, or as an alternate option, for solving the issue of funding student-athletes.

\section{Limitations and Future Research}

As with all forms of research, this model came with its own limitations. First, this paper sought to explore a new way to potentially compensate student-athletes through various equations. This model is in no way intended to be the only athlete compensation model available, as other models should be proposed and explored. Legal aspects of the model were not included, but it is recognized that this model would need to go through proper legal footholds before it could be implemented. Future research on the legality of the model in terms of antitrust legislation would be necessary moving forward. Next, the Student-Athlete Compensation Model looked only at one school in the NCAA. Future scholars can use this model, or others, to examine its potential effects on the entirety of the NCAA's Division I schools. This model was developed with a studentathlete-first mindset, as opposed to the revenues and expenses of the NCAA, the NCAA's conferences, and individual athletic departments. This model was proposed with the intent of adding a new dimension to player compensation conversations, and should be used as a building block for future developments. This case study was at the mercy of figures reported to the NCAA, which did not differentiate gifts in-kind from revenue generation. For this equation to properly 
work, true revenue numbers should be reported to the NCAA separately from revenues generated. Future research should further investigate how the NCAA decides which numbers should be reported. 


\section{References}

Anthony, S. D. (2009). Major league innovation: Major League Baseball's sabermetrics, depth charts, and farm systems are a source of inspiration for executives who must deliver growth-fueling innovation. Harvard Business Review, 51-56.

Arash, A. (2014). Collegiate athletes: The conflict between NCAA amateurism and a student athlete's right of publicity. Willamette Law Review, 51, 99-131.

Berri, D. J. (2012). Did the players give up money to make the NBA better? Exploring the 2011 collective bargaining agreement in the National Basketball Association. International Journal of Sport Finance, 7(2), 158-175.

Berry III, W. W. (2013). Educating athletes: Re-envisioning the student-athlete model. Tennessee Law Review, 81, 795.

Camara, A. (2009). Earnings-based bonus compensation. The Financial Review, 44, 469-488.

Costa, G.B. (1991). Baseball in the university classroom: Sabermetrics. Education, 112(2), 273-276.

Dennie, C. (2012). Changing the game: The litigation that may be the catalyst for change in intercollegiate athletics. Syracuse Law Review, 62, 15-51.

Gales, J. G., Comeaux, E., Ofoegbu, E., \& Grummert, S. (2018). Neoliberal capitalism and racism in college athletics: Critical approaches for supporting student-athletes. New Directions for Student Services, 2018(163), 11-21.

Greene, B. (2012). What changed the Olympics forever. CNN.com. Retrieved from http://www.cnn.com/2012/07/22/opinion/greene-olympics-amateurs/

Hill, J. R., \& Jolly, N. A. (2015). Revenue sharing and player salaries in Major League Baseball. Journal of Sports Economics. doi: 10.117/1527002515609660 
Huma, R., \& Staurowsky, E. J. (2013). The price of poverty in big time college sport. Retrieved from National College Players Association website: http://assets.usw.org/ncpa/The-Priceof-Poverty-in-Big-Time-College-Sport.pdf

Kirshner, A. (2018). Here's how the NCAA generated a billion dollars in 2017: It's the first time the NCAA has cleared \$1 billion in annual revenue. It won't be the last. SBNation.com. Retrieved from https://www.sbnation.com/2018/3/8/17092300/ncaa-revenues-financialstatement-2017

McCann, M. (2018a, April 2). Jenkins v. NCAA: College amateurism, scholarship rules go on trial. Sports Illustrated. Retrieved from https://www.si.com/collegefootball/2018/04/02/ncaa-amateurism-trial-judge-wilken-martin-jenkins-scholarships

McCann, M. (2018b, Sept. 4). Alston v. NCAA: Analyzing college sports' grant-in-aid trial. Sports Illustrated. Retrieved from https://www.si.com/collegefootball/2018/09/04/alston-v-ncaa-trial-news-updates-ncaa-cost-attendance

Mills, B., \& Winfree, J. (2018). Athlete pay and competitive balance in college athletics. Review of Industrial Organization, 52(2), 211-229.

Moreno, P., \& Lozano, S. (2015). Estimation of productivity change of NBA Teams from 2006-07 to 2012-13 seasons. International Journal of Sport Finance, 10, 217-241.

Moyer, A. (2015). Throwing out the playbook: Replacing the NCAA's anticompetitive amateurism regime with the Olympic model. The George Washington Law Review, $83,761-828$.

NCAA Division I Manual (2018-19). Indianapolis, IN: National Collegiate Athletic Association.

Nestle, D. (1992). Athletic scholarships: An imbalance of power between the university and the student-athlete. Ohio State Law Journal, 53(3), 1401-1420.

O'Bannon v. National Collegiate Athletic Association, 7 F. Supp. 3d 955 (N.D. Cal. 2014).

O'Bannon v. National Collegiate Athletic Association, 802 F.3d 1049 (9th Cir. 2015). 
Otto, K. A., \& Otto, H. R. (2013). Clarifying amateurism: A logical approach to resolving the exploitation of college athletes dilemma. Sport, Ethics and Philosophy, 7(2), 259270.

Sanderson, A., \& Siegfried, J. (2015). The case for paying college athletes. The Journal of Economic Perspectives, 29, 115-137.

Santesteban, C. J., \& Leffler, K. B. (2017). Assessing the efficiency justifications for the NCAA player compensation restrictions. Antitrust Bulletin, 62, 91-111. Retrieved from http://libproxy.unm.edu/login?url=https://search.ebscohost.com/login.aspx?direct=true\&d $\mathrm{b}=1 \mathrm{fh} \& \mathrm{AN}=121291956 \&$ site $=$ ehost-live \&scope $=$ site

Schott, S. (1996). Give them what they deserve: Compensating the student-athlete for participation in intercollegiate athletics. Sports Lawyers Journal, 3, 25-50.

Smith, M., \& Ourand, J. (2008, August 25). ESPN pays \$2.25B for SEC rights. Street \& Smith's SportsBusiness Journal. Retrieved from http://www.sportsbusinessdaily.com/Journal/Issues/2008/08/20080825/This-WeeksNews/ESPN-Pays-\$225B-For-SEC-Rights.aspx

Solomon, J. (2015, August 20). 2015-16 CBS Sports FBS college football cost of attendance database. Retrieved from http://www.cbssports.com/video/player/embed

Southall, R. M., \& Staurowsky, E. J. (2013). Cheering on the collegiate model: Creating, disseminating, and imbedding the NCAA's redefinition of amateurism. Journal of Sport \& Social Issues, 37(4), 403-429.

Staurowsky, E. J., \& Sack, A. L. (2005). Reconsidering the use of the term student-athlete in academic research. Journal of Sport Management, 19, 103-116.

Steele, M. (2015). O'Bannon V. NCAA: The Beginning of the end of the amateurism justification for the NCAA in antitrust litigation. Marquette Law Review, 99, 511-540.

U.S. Department of Education. (2015). Tuition cost for universities and colleges. Retrieved from http://nces.ed.gov/FastFacts/display.asp?id=76 
Vrooman, J. (2012). The economic structure of the NFL. In K. G. Quinn (Ed.), The economics of the National Football League: The state of the art (pp. 7-32). New York: NY: Springer.

Zimbalast, A. (2010). Reflections on salary shares and salary caps. Journal of Sports Economics, 11, 17-28. 